\title{
Partial characterization of digestive proteases in juveniles of Microphis brachyurus (short-tailed pipefish) (Syngnathiformes: Syngnathidae)
}

Correspondence:

Carlos A. Álvarez-González alvarez_alfonso@hotmail.com
Submitted August 5, 2019

Accepted May 6, 2020

by Juan Miguel Mancera

Epub Jun 26, 2020
Online version ISSN 1982-0224

Print version ISSN 1679-6225

Neotrop. Ichthyol.

vol. 18, no. 2, Maringá 2020

\section{${ }^{\oplus}$ Leonardo Martínez-Cárdenas ${ }^{1},{ }^{\oplus}$ Carlos A. Frías-Quintana ${ }^{2}$, ${ }^{\oplus}$ Carlos A. Álvarez-González ${ }^{3},{ }^{\oplus}$ Luis D. Jiménez-Martínez ${ }^{4}$, ${ }^{\oplus}$ Rafael Martínez-García ${ }^{3}{ }^{\oplus}$ Oscar U. Hernández-Almeida ${ }^{1}$, ${ }^{\oplus}$ Javier Bello-Pineda ${ }^{5},{ }^{\oplus}$ Leonardo U. Arellano-Méndez ${ }^{6}$ and Jesús T. Ponce-Palafox ${ }^{7}$}

Short-tailed pipe fish (Microphis brachyurus) is a freshwater organism with high economic potential for the aquarium hobby, so it is necessary to implement methods to promote its culture through studies of digestive physiology. General activities of acid and alkaline proteases were evaluated, as well as the effect of $\mathrm{pH}$, temperature and inhibitors. The optimal $\mathrm{pH}$ of stomach proteases was 2, while the optimal $\mathrm{pH}$ of intestinal proteases was 10 . Optimal temperature for the acidic proteases was $35{ }^{\circ} \mathrm{C}$, while for alkaline proteases it was $45^{\circ} \mathrm{C}$. Thermal stability showed high resistance at $35{ }^{\circ} \mathrm{C}$ for both acid and alkaline proteases (above 100\% residual activity). Acid proteases are resistant at $\mathrm{pH} 2$ (50\% of residual activity), meanwhile alkaline proteases were highly resistant at $\mathrm{pH} 10$ (90\% of residual activity). Acid proteases were inhibited by $80 \%$ with pepstatin A and alkaline proteases were inhibited with TLCK and TPCK for trypsin (75\%) and chymotrypsin (80\%), respectively. Finally, metallo-proteases were $75 \%$ partially inhibited some serine proteases by $75 \%$ with EDTA. In conclusion, $M$. brachyurus has a good digestive capacity, since they can degrade a wide variety of proteins due to their greater proteolytic activity.

Keywords: Enzyme activity, Sygnathidae, pH, Protease inhibitors, Temperature.

\footnotetext{
1 Secretaria de Investigación y Posgrado, Universidad Autónoma de Nayarit, 63155 Tepic, Nayarit, Mexico. (LMC) leonarm2@yahoo.com.mx; (OUHA) ubisha@uan.edu.mx.

2 Laboratorio de Investigación en Biotecnología Acuícola (LIBA), Tecnológico Nacional de México Campus Boca del Río (ITBoca). Carretera Veracruz-Córdoba Km.12, 94290 Boca del Río, Veracruz, Mexico. (CAFQ) cafq22@hotmail.com.

3 Laboratorio de Acuicultura Tropical, División Académica de Ciencias Biológicas, Universidad Juárez Autónoma de Tabasco, 86150 Villahermosa, Tabasco, Mexico. (CAAG) alvarez_alfonso@hotmail.com (corresponding autor); (RMG) biologomartinez@hotmail.com.

4 División Académica Multidisciplinaria de Jalpa de Méndez, Universidad Juárez Autónoma de Tabasco, 86205 Jalpa de Méndez, Tabasco, Mexico. (LDJM) luisd1984@hotmail.com

5 Instituto de Ciencias Marinas y Pesquerías; Laboratorio de Análisis espacial para la toma de decisiones, Universidad Veracruzana, Hidalgo 617, Col. Río Jamapa, 94290 Boca del Río, Veracruz, Mexico. (JBP) bellopj@yahoo.com.

6 Instituto de Ecología Aplicada, Universidad Autónoma de Tamaulipas, División del Golfo 356, Col. Libertad, 87019 Ciudad Victoria, Tamaulipas, Mexico. (LUAM) luarellano@uat.edu.mx.

7 Universidad Autónoma de Nayarit, Escuela Nacional de Ingeniería Pesquera, Laboratorio de Bioingeniería Costera, Centro Multidisciplinario de Bahía Banderas, 63740 San Blas, Nayarit, Mexico. (JTPP) jesus.ponce@usa.net.
} 
El pez pipa (Microphis brachyurus) es un organismo dulceacuícola con alto potencial económico para la acuarofilia; sin embargo, es necesario implementar su cultivo a través de estudios de fisiología digestiva. Se evaluó el efecto del $\mathrm{pH}$, temperatura e inhibidores sobre las actividades enzimáticas de proteasas ácidas y alcalinas. El pH óptimo de proteasas estomacales es de 2 , mientras que el de proteases intestinales es de 10 . La temperatura óptima de proteasas ácidas es de $35^{\circ} \mathrm{C}$ y las alcalinas de $45^{\circ} \mathrm{C}$. La estabilidad térmica para proteasas ácidas y alcalinas es a los $35^{\circ} \mathrm{C}$ (más de $100 \%$ de actividad residual). La estabilidad a los diferentes $\mathrm{pH}$ de las proteasas ácidas es en 2 (50\% de la actividad residual), mientras que para las proteasas alcalinas es en 10 (90\% de la actividad residual). Las proteasas ácidas fueron inhibidas en $80 \%$ con pepstatina A y las proteasas alcalinas fueron altamente inhibidas con TLCK para tripsina (75\%) y TPCK quimitripsina (80\%). Finalmente, las metaloproteasas fueron inactivadas con EDTA en $70 \%$. En conclusión, M. brachyurus tiene una buena capacidad digestiva al degradar una amplia variedad de proteinas debido a su alta actividad proteolítica.

Palabras clave: Actividad enzimática, Inhibidores de proteasas, pH, Sygnathidae, Temperatura.

\section{INTRODUCTION}

The short-tailed pipefish, Microphis brachyurus (Bleeker, 1854), is a subtropical estuarine fish, distributed along the Gulf of Mexico. It belongs to the Syngnathidae family, which includes sea dragons, seahorses, and pipefish. The main characteristic of syngnathids is male parental care, as eggs are glued by females either to the ventral male structures or deposited into the male brood pouch (Wilson et al., 2001). In Mexico, populations of native fishes are under pressure due to anthropogenic alteration of habitat and introduction of exotic species (Jelks et al., 2008). The subspecies, M. brachyurus lineatus, has been considered as a species of concern since 1991 in the USA by the National Oceanic and Atmospheric Administration (NOAA, 2004). Natural populations of $M$. brachyurus are also affected in Mexico by unregulated fishing as this species is traded as an aquarium fish without formal records as occurs with other syngnathid species around the world (Rosa et al., 2011). Approximately 37 species of pipefish have been reported to inhabit both freshwater and saltwater systems (Nelson et al., 2016), including $M$. brachyurus, which often faces inadequate culture practices in the average home aquarium as it is maintained in tanks with conventional freshwater tropical fish.

However, survival of $M$. brachyurus in captivity is compromised by conventional fish diets (flakes, pellets, and frozen Artemia), whereas the species naturally preys on live items, mainly crustaceans and fish larvae small enough to be ingested by the characteristic reduced mouth of the Syngnathidae family (Miller et al., 2005).

In recent years, there has been a growing interest in developing technologies with native species for their culture at commercial scale. However, the knowledge for $M$. brachyurus production is unknown, particularly in relation to their digestive physiology. Currently, research efforts are aimed at determining the conditions that increase the 
survival and viability of culture production, as well as to characterize digestive physiology, in order to better plan and feed design. In this last case, the studies are based on the detailed knowledge of the digestive physiology in the different stages of life by means of the determination of the digestive enzymatic activities and characterization of proteases, as it is known that the of activity of some enzymes acts as a good indicator of nutritional, so that the data obtained may be relevant to establish an optimal artificial feeds and to reduce production costs in hatcheries (Ueberschär, 1995). Recently, several studies have been conducted to relate the appearance of digestive enzymes with physiological and nutritional features in various species such as Atractosteus tropicus Gill, 1863, Cichlasoma urophthalmus (=Mayaheros urophthalmus (Günther, 1862)), Cichlasoma trimaculatum (=Amphilophus trimaculatus (Günther, 1867)), Lutjanus guttatus (Steindachner, 1869), Chelon labrosus (Risso, 1827), Centropomus undecimalis (Bloch, 1792), Cichlasoma beani (=Mayaheros beani (Jordan, 1889)), and Archosargus probatocephalus (Walbaum, 1792) (Cuenca-Soria et al., 2014; Guerrero-Zárate et al., 2014; Peña et al., 2015; Toledo-Solís et al., 2015; Concha-Frias et al., 2016; Pujante et al., 2017; Martínez-Cárdenas et al., 2017; Merino-Contreras et al., 2018). In this way, this work aims to characterize the digestive proteases in juveniles of Microphis brachyurus.

\section{MATERIAL AND METHODS}

Sample Preparation. For this study, 132 pipefish juveniles with a weight $0.25 \mathrm{~g} \pm 0.3$ $\mathrm{SD}$ and length $89.6 \mathrm{~mm} \pm 0.5 \mathrm{SD}$, were captured in the Jamapa River $\left(19^{\circ} 05^{\prime} 40.42 ” \mathrm{~N}\right.$, $\left.96^{\circ} 08^{\prime} 23.40^{\prime \prime W}\right)$. After collection, they were transported in an insulated water tank containing water at $26^{\circ} \mathrm{C}$ and $8 \mathrm{~g} \mathrm{~L}^{-1}$ salinity (recorded at collection) to the wet laboratory located in Tepic, Nayarit. Fish were subsequently sacrificed with an overdose of tricaine methanesulfonate (MS-222, Sigma-Aldrich, Saint Louis, MI, USA). The total weight and length of each fish was recorded and subsequently, the stomach and intestine were extracted individually on a frozen plate. Subsequently, the organs were lyophilized and preserved at $-20{ }^{\circ} \mathrm{C}$ until processing. Dried organs were sent to the Biochemistry Laboratory in the División Académica de Ciencias Biológicas at Universidad Juárez Autónoma de Tabasco. Stomachs were homogenized in a proportion of $200 \mathrm{mg} \mathrm{mL}^{-1}$ in $100 \mathrm{mmol} \mathrm{L}^{-1}$ of glycine- $\mathrm{HCl}$ buffer at $\mathrm{pH}$ 2, while Tris- $\mathrm{HCl}$ buffer $12.5 \mathrm{mmol} \mathrm{L}^{-1}$ $+30 \mathrm{mmol} \mathrm{L}^{-1} \mathrm{CaCl}_{2} \mathrm{~L}^{-1}$ at $\mathrm{pH} 7.5$ was used for the intestines, in the same proportion respectively. The homogenate was centrifuged at $16,000 \times \mathrm{g}$ for $30 \mathrm{~min}$ at $4{ }^{\circ} \mathrm{C}$; the multienzyme extract thus obtained was stored at $-80{ }^{\circ} \mathrm{C}$ for further analysis. The concentration of soluble protein was determined using the Bradford (1975) technique with the bovine serum albumin as the standard.

Biochemical Analyses. The total activity of the acid proteases was determined using $1 \%$ hemoglobin in $100 \mathrm{mmol} \mathrm{L}^{-1}$ glycine- $\mathrm{HCl}$ buffer at $\mathrm{pH} 2$ following the method of Walter (1984). The activity of alkaline proteases was evaluated following the method of Anson (1938), as modified by Kunitz (1947), using 1\% casein in $100 \mathrm{mmol} \mathrm{L}^{-1}$ Tris$\mathrm{HCl}+10 \mathrm{mmol} \mathrm{L}^{-1} \mathrm{CaCl}_{2}$ buffer at $\mathrm{pH}$ 9. One unit of activity was defined as $1 \mu \mathrm{g}$ of tyrosine liberated per minute with a Molar Extinction Coefficient (MEC) of 0.005 $\mathrm{mL}^{-1} \mathrm{Hg}^{-1} \mathrm{~cm}^{-1}$. To determine the MEC of tyrosine, a standard curve was made with 
different concentrations of tyrosine (from 0 to $300 \mathrm{mg} \mathrm{mL}^{-1}$ ). All trials were performed in triplicate.

Effects of $\mathrm{pH}$ and Temperature on Digestive Enzyme Activity. The optimum $\mathrm{pH}$ of the acid and alkaline proteases was evaluated using a universal buffer Stauffer (1989) with a $\mathrm{pH}$ range of 2-12 following the technique of Walter (1984) and Anson (1938), previously described to determine protease activity. The optimum temperature of the acid and alkaline proteases was established by enzyme assays at different temperatures $\left(35,45,55,65^{\circ} \mathrm{C}\right)$. The effects of $\mathrm{pH}$ and temperature on the stability of acid and alkaline proteases were determined by pre-incubating the multienzyme extracts for 0, 30, 60 and 90 min with a buffer at the assay temperature (Stauffer, 1989). For the determination of the stability under different conditions of $\mathrm{pH}$ and temperature the pre-incubation time 0 min value was used as a control to determine the residual activity expressed as a percentage of residual activity comparing with the extracts that were incubated at different $\mathrm{pH}$ and temperatures.

Zymograms and Effects of Inhibitors. Electrophoretic analyses were performed with a Mini-PROTEAN 3 Cell (Bio-Rad) with four plates containing vertical gels $(8 \times 10 \times 0.075 \mathrm{~cm})$ with $10 \mathrm{~mL}$ sample capacity per plate. For the analysis of alkaline proteases, the plate was prepared by stacking a gel with $4 \%$ polyacrylamide (PAA) and resolving the gel with 10\% PAA. Electrophoresis was run under denaturalizing conditions (SDS-PAGE), with 0.1\% SDS Tris buffer $\left(25 \mathrm{mmol} \mathrm{L}^{-1}\right)$ and glycine (192 mmol L-1 $\mathrm{pH} 8.3$, 100 volts), according to Laemmli (1970), and adapted by GarcíaCarreño et al. (1993). The gels were treated to reveal proteases isoforms according to the procedure of Díaz-López et al. (1998). They were washed and incubated for 30 min at $5^{\circ} \mathrm{C}$ in a $0.5 \%$ casein solution (Tris- $\mathrm{HCl} 100 \mathrm{mmol} \mathrm{L}{ }^{-1}$ buffer, $\mathrm{pH}$ 9), then gels were incubated for $90 \mathrm{~min}$ in the same solution at $37{ }^{\circ} \mathrm{C}$, and then washed and fixed in trichloroacetic acid (12\%) solution for $15 \mathrm{~min}$. Areas of enzyme activity were developed according to Weber, Osborn (1969), using a 0.1\% Coomassie brilliant blue R-250 solution to stain the gels, while further distaining was carried out in a 35:10:55 solution of methanol-acetic acid-water. Clear zones revealed the activity of proteases within few minutes, although well-defined zones were obtained after $2-4 \mathrm{~h}$. The inhibitors were used for the alkaline proteases: phenyl-methanesulphonyl fluoride 100 mmol L-1 (PMSF), N-q-tosyl-lysine-chloromethyl ketone hydrochloride $10 \mathrm{mmol} \mathrm{L}^{-1}$ (TLCK), soybean trypsin inhibitor $250 \mathrm{mmol} \mathrm{L}^{-1}$ (SBT1), N-q-tosyl-L-phenylalanine chloromethyl ketone $10 \mathrm{mmol} \mathrm{L}^{-1}$ (TPCK), 1,10-phenanthroline $10 \mathrm{mmol} \mathrm{L}^{-1}$ (Phen), trypsin inhibitor, type II-T: turkey egg ovoalbumine $250 \mathrm{mmol} \mathrm{L}^{-1}$ (Ovo) and ethylene diamine tetra acetic acid $10 \mathrm{mmol} \mathrm{L}^{-1}$ (EDTA). Extracts were incubated in the presence of each inhibitor for $1 \mathrm{~h}(1: 1 \mathrm{v} / \mathrm{v})$ at $\mathrm{pH} 7.5$, the $\mathrm{pH}$ value of intestine extracts, and at $\mathrm{pH} 2$ for stomach extracts during sample preparation. In both tests a control without inhibitor was used as $100 \%$ of total activity and the residual activity was expressed as a percentage of reduction of the activity with the different inhibitors (Dunn, 1989). They were pre-incubated in a 1:1 ratio (enzyme: inhibitor) for $1 \mathrm{~h}$. The molecular weight marker SDS-PAGE standards unstained Low Range (Biorad cat. 1610304) and the program Quantity One 1-D Analysis Software de Bio-Rad® were used to calculate the molecular weight of each active bands. 
Statistical Analysis. All the enzymatic activity assays were carried out in triplicate of the same homogenate and were evaluated by means of nonparametric statistical analysis of Kruskal-Wallis test and a posteriori Nemenyi test as the data were not normally distributed. Statistical tests were conducted with the Statistica software v. 7.5 (Statsoft, Tulsa, OK, USA) using a significance value of 0.05 .

\section{RESULTS}

The optimum $\mathrm{pH}$ for the activity of acid proteases was 2 (Fig. 1A) and for alkaline proteases activity the $\mathrm{pH}$ optimum was 10 (Fig. 1B). After 30 min preincubation, the remaining enzyme activity for acid proteases was $50 \% \mathrm{pH} 2$, while the remaining activities were around $15 \%-20 \%$, at $\mathrm{pH} 4-7$ after 90 min pre-incubation (Fig. 1C). The maximum $\mathrm{pH}$ stability of alkaline proteases occurred after 30 minutes of preincubation at $\mathrm{pH} 10$, showing a decrease in its residual activity until reaching $90 \%$ after 90 minutes of preincubation (Fig. 1D).

The optimum temperature for acidic proteases was $35^{\circ} \mathrm{C}$ (Fig. $2 \mathrm{~A}$ ) and optimum temperature of alkaline protease activity was $45^{\circ} \mathrm{C}$ (Fig. 2B). The stability of the acidic proteases presented thermal variations above $100 \%$ at $35{ }^{\circ} \mathrm{C}$ (Fig. 2C). Instead, maximal stability of alkaline protease was observed at $35{ }^{\circ} \mathrm{C}$, which decreased after 90 minutes
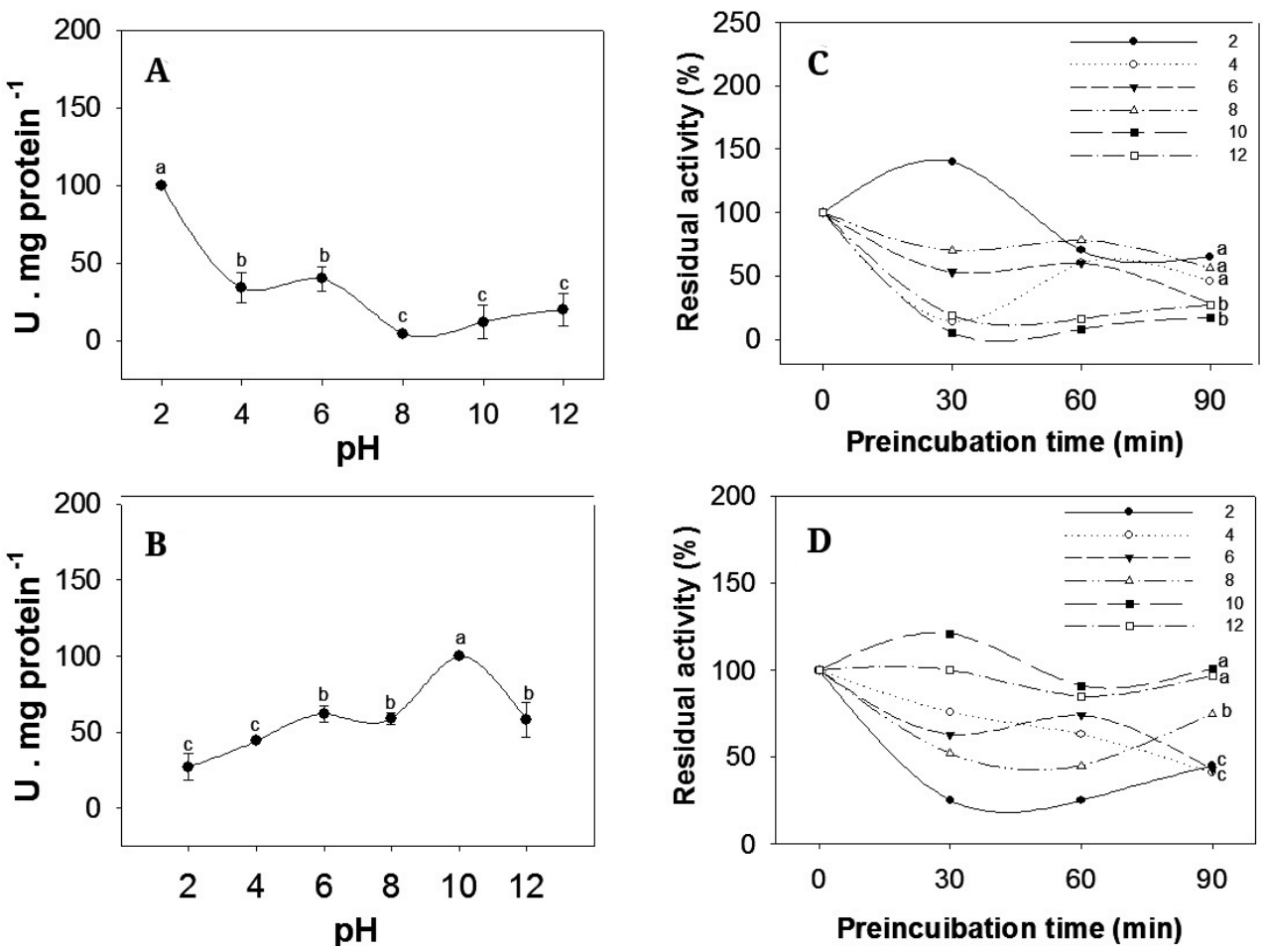

FIGURE 1 I Effect of $\mathrm{pH}$ on the enzymatic activity of digestive proteases of short-tailed pipefish (Microphis brachyurus) juveniles for the determination of: A. optimal pH of acidic proteases; B. optimal $\mathrm{pH}$ of alkaline proteases; $\mathbf{C}$. pH stability of acidic proteases; and $\mathbf{D}$. pH stability of alkaline proteases (mean $\pm \mathrm{SD}, \mathrm{n}=3$ ). Mean values denoted with different letters are statistically different, $\mathrm{p}<0.05$. 
of preincubation, followed by the temperature of $45{ }^{\circ} \mathrm{C}$ where the activity remained stable, while temperatures of 55 and $65{ }^{\circ} \mathrm{C}$ decreased the activity to $40-55 \%$ at $90 \mathrm{~min}$ preincubation (Fig. 2D).

Analysis of the effects of inhibitors indicated that acid protease was inhibited by $80 \%$ by pepstatin A, a specific inhibitor of pepsin type A enzymes. The activity of alkaline proteases showed an inhibition of $75 \%$ of activity by TLCK, a specific inhibitor of trypsin, inhibition of $80 \%$ of activity by TPCK, a specific inhibitor of chymotrypsin; activity inhibition of $58 \%$ by SBT1 and $35 \%$ by ovalbumin, which inhibit serine proteases, a reduction of $55 \%$ and $75 \%$ of activity by the metalo-protease inhibitors Phenanthroline and EDTA, respectively, and inhibition of $40 \%$ of activity by PMSF, a general inhibitor of serine proteases (Fig. 3).

The analysis of SDS-PAGE zymograms for alkaline proteases revealed six active bands in control without inhibitor $(87.9,64.8,59.7,52.6,38.1$ and $35.2 \mathrm{kDa})$. TPCK inhibited four active bands $(87.9,59.7,52.6$ and $35.2 \mathrm{kDa})$, Phenanthroline and EDTA inhibited five active bands $(87.9,64.8,59.7,52.6$ and $35.2 \mathrm{kDa})$, TLCK inhibited four active bands $(87.9,64.8,59.7,52.6 \mathrm{kDa})$, Ovalbumin inhibited four active bands (64.8, 59.7, 52.6, and $35.2 \mathrm{kDa}$ ), while SBT1 inhibited three active bands (64.8, 59.7 and 35.2 $\mathrm{kDa}$ ) and PMSF inhibited two active bands (64.8 and $59.7 \mathrm{kDa}$ respectively) (Fig. 4).
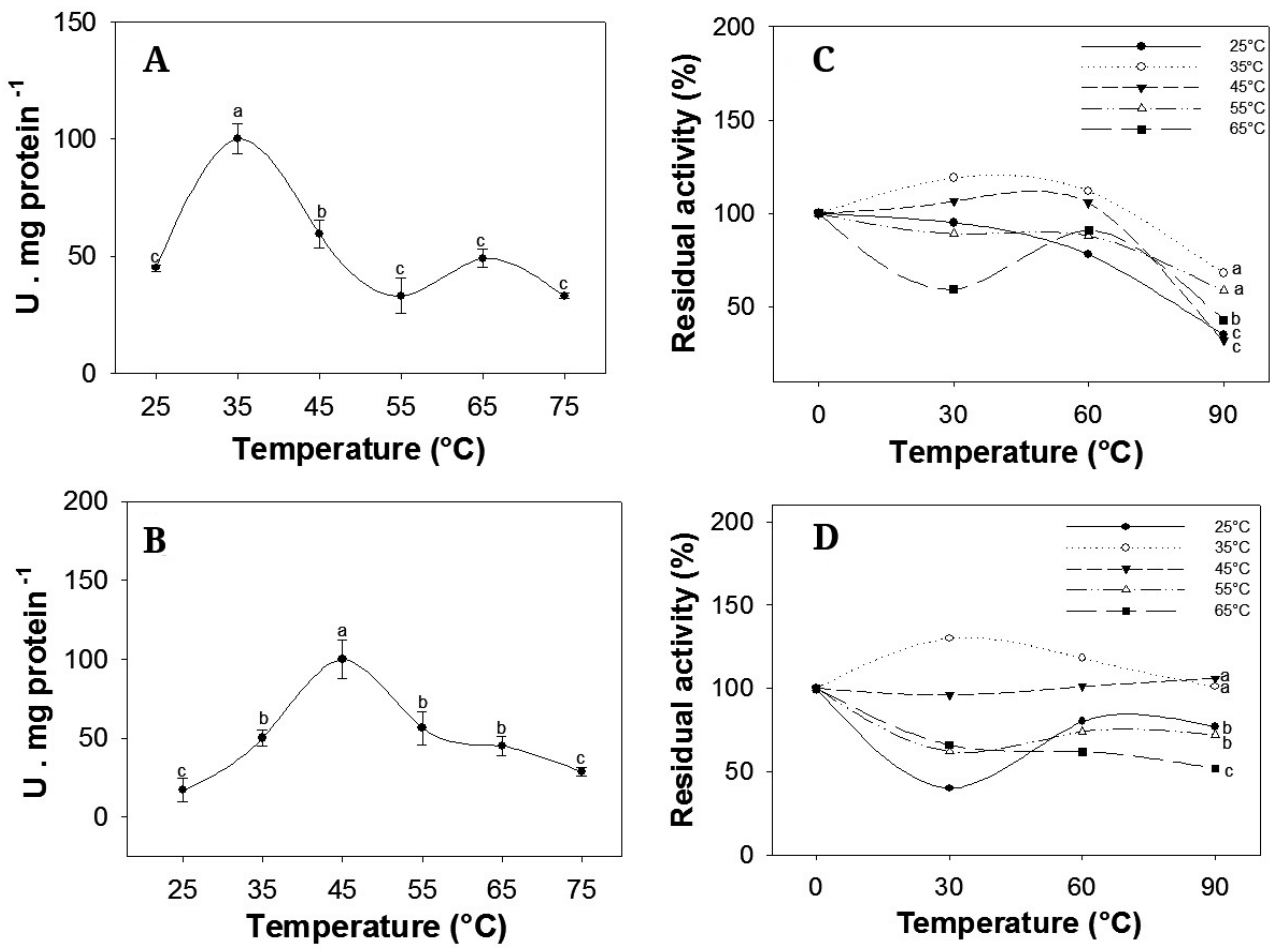

FIGURE 2 I Effect of temperature on digestive proteases of juvenile of short-tailed pipefish (Microphis brachyurus): A. optimum temperature of acidic proteases; B. thermal stability of acidic proteases; C. optimum temperature of alkaline proteases; and $\mathbf{D}$. thermal stability of alkaline proteases (mean $\pm S D$, $\mathrm{n}=3$ ). Mean values denoted with different letters are statistically different, $\mathrm{p}<0.05$. 


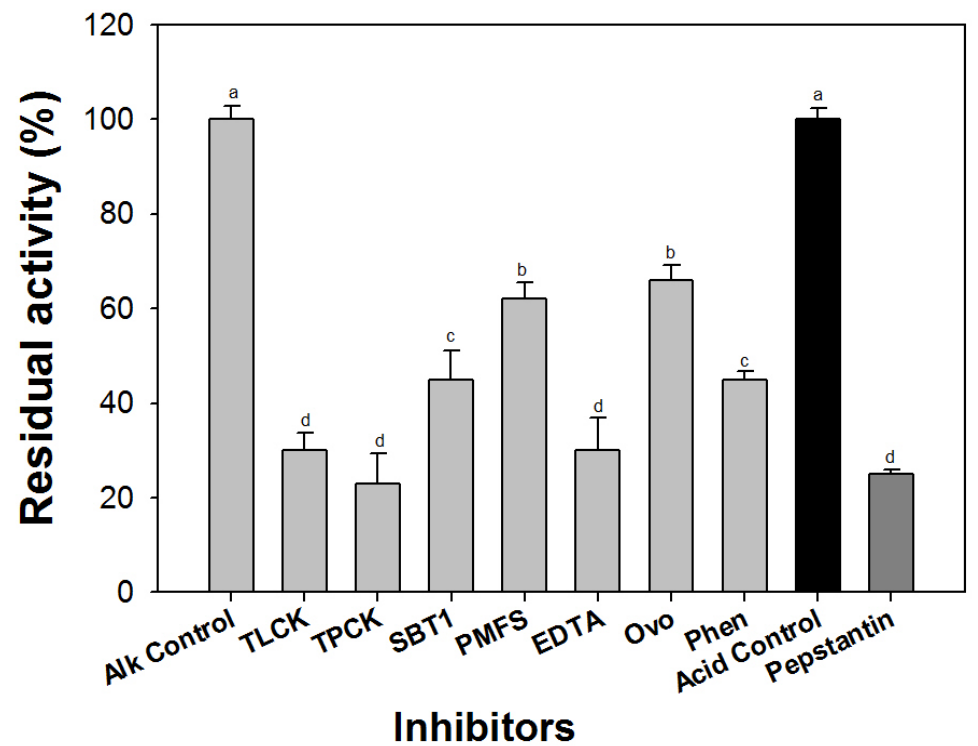

FIGURE 3 I Residual activity (\%) of digestive proteases using several inhibitors on multienzyme extracts of short-tailed pipefish (Microphis brachyurus) juveniles. Alkaline proteases with no inhibitor (Alk control), tosylphenylanylchloromethyl ketone (TPCK), phenanthroline (PHEN), ethyl-diamine tetra-acetic acid (EDTA), tosyllysyl- chloromethyl ketone (TLCK), ovalbumin (OVO), soybean trypsin inhibitor (SBT1), phenyl methyl sulphonyl fluoride (PMSF), acidic proteases with no inhibitor (Acid control), pepstatin $\mathrm{A}($ mean $\pm \mathrm{SD}, \mathrm{n}=3$ ). Columns with different letters represent significant differences $(\mathrm{p}<0.05)$.

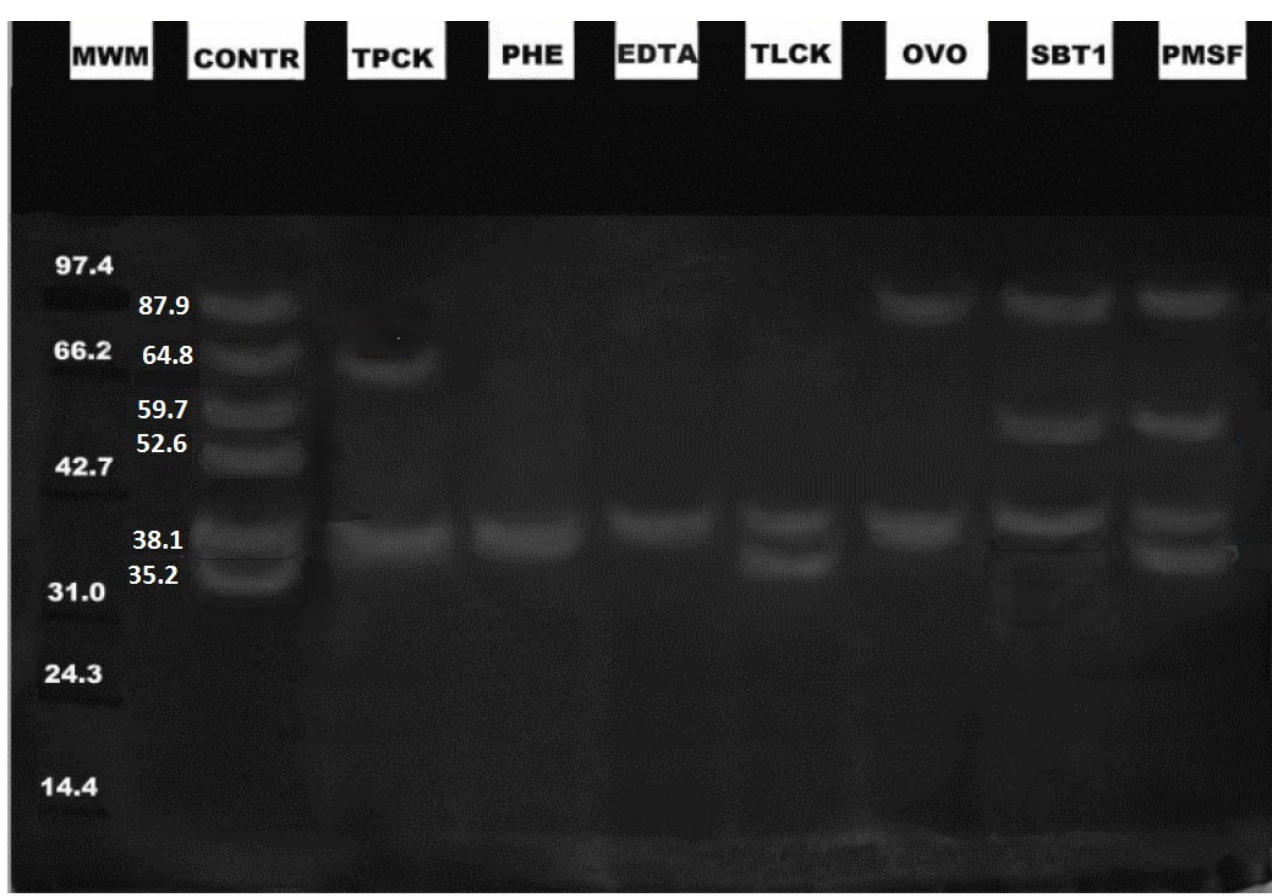

FIGURE 4 I SDS-PAGE zymogram of alkaline digestive proteases of short-tailed pipefish (Microphis brachyurus) juveniles: Molecular weight marker (MWM), rabbit phosphorylase B (97.4 kDa), bovine serum albumin (66.2 kDa), ovalbumin (42.7 kDa), carbon anhydrase (31.0 kDa) and lysozyme (14.4 kDa); control (without inhibitor); inhibitors were the same as in Fig. 3. 


\section{DISCUSSION}

The results obtained in the enzymatic characterization of juveniles of short-tailed pipefish (Microphis brachyurus) showed that this species exhibits a relatively high activity of alkaline digestive proteases compared with other fish species such as Scleropages formosus (Müller, Schlegel, 1840) (Natalia et al., 2004), turbot Scophthalmus maximus (Linnaeus, 1758) (Wang et al., 2006), Mayan cichlid Cichlasoma uropthalmus (CuencaSoria et al., 2014), Cichlasoma trimaculatum (=Amphilophus trimaculatus) (Toledo-Solís et al., 2017), and Cichlasoma beani (=Mayaheros beani) (Mártinez-Cárdenas et al., 2017). The latter two species have carnivorous habits characterized by high acid protease activities (>1500 Unit Enzymatic Activity (UEA) mg of protein $^{-1}$ ) in the stomach, which is the most important organ for the acid digestion of proteins, as well as a lower alkaline digestive activity in the intestine ( $<250$ UEA mg protein $\left.{ }^{-1}\right)$ that is in charge of the hydrolysis of large peptides to release small peptides and amino acids to be absorbed by enterocytes (García-Carreño et al., 2002).

In the present study, acid proteases reached their maximum activity at $\mathrm{pH} 2$, which is consistent with findings of the majority of previous studies for species such as Solea senegalensis Kaup, 1858 (Yúfera, Darías, 2007), Symphysodon aequifasciatus Pellegrin, 1904 (Chong et al., 2002), Diplodus puntazzo (Walbaum, 1792) (Tramati et al., 2005), Latimeria chalumnae Smith, 1939 (Tanji et al., 2007), Nemipterus spp. (Nalinanon et al., 2008), and Acipenser naccarii Bonaparte, 1836 (Furné et al., 2005). However, Oncorhynchus mykiss (Walbaum, 1792) and Petenia splendida Günther, 1862 have higher optimum $\mathrm{pH}$ values ( 5 and 4 respectively) for acid and alkaline enzymes, that is uncommon for acid digestion (Furné et al., 2005; Uscanga-Martínez et al., 2011) and different to that found in M. brachyurus. For proteases, $\mathrm{pH}$ is a chemical key factor at which activity can be maximized, as allowing the active center of the enzymes to join the anchor site (enzyme-substrate binding) to perform a highly efficient catalysis (Álvarez-González, 2003).

In $M$. brachyurus, alkaline digestive proteases showed an optimum $\mathrm{pH}$ at 10 , which has been recorded for other marine and freshwater fish species such as Brycon orbignyanus (Valenciennes, 1850) (García-Carreño et al., 2002), Symphysodon aequifasciatus (Chong et al., 2002); D. puntazzo (Tramati et al., 2005), Oreochromis niloticus (Linnaeus, 1758) x O. aureus (Steindachner, 1864) (Jun-sheng et al., 2006), Catla catla (=Labeo catla (Hamilton, 1822)), Labeo rohita (Hamilton, 1822), and Hypophthalmichthys molitrix (Valenciennes, 1844) (Kumar et al., 2007); Thunnus orientalis (Temminck, Schlegel, 1844) (de la Parra et al., 2007), Ctenopharyngodon idella (Valenciennes, 1844) (Liu et al., 2008); Cichlasoma uropthalmus (Cuenca-Soria et al., 2014), Cichlasoma trimaculatum (=Amphilophus trimaculatus) (Toledo-Solís et al., 2017), Cichlasoma beani (=Mayaheros beani) (MártinezCárdenas et al., 2017), and Archosargus probatocephalus (Merino-Contreras et al., 2018). However, some studies have reported different $\mathrm{pH}$ optimum; even two $\mathrm{pH}$ values of maximum activity have been recorded as in Palabrax maculatofasciatus (Steindachner, 1868) (Álvarez-González, 2003) and C. undecimalis (Concha-Frias et al., 2016). This is possible because the multienzymatic extract could be composed of different digestive proteases with similar specificity or by different isoforms of the same enzyme, with different optimum $\mathrm{pH}$ (Alarcón et al., 1998). Finding of a well-defined optimum $\mathrm{pH}$ in $M$. brachyurus suggests a major contribution of enzymes that share the same $\mathrm{pH}$ 
optimum (de la Parra et al., 2007).

On the other hand, digestive acid proteases in M. brachyurus are stable at acid $\mathrm{pH}(2)$ and their activity decreases with increasing $\mathrm{pH}$ values. In contrast, alkaline proteases are stable in alkaline $\mathrm{pH}$ and are resistant to slightly acidic conditions, similar to that reported in the freshwater cichlid P. splendida (Uscanga-Martínez et al., 2011). In contrast, the acidic (stomach) proteases of marine fish are stable for a very short time at alkaline pH conditions, as reported for T. thynnus (Linnaeus, 1758) (Essed et al., 2002) and S. maximus (Wang et al., 2006). This has also been found in omnivore marine species such as S. senegalensis (Sáenz de Rodrigáñez et al., 2005) and carnivorous freshwater species such as $A$. tropicus (Guerrero-Zárate et al., 2014). This could hardly occur in $M$. brachyurus because acid proteases lose activity at a neutral or alkaline $\mathrm{pH}$. However, this loss of activity is compensated, by the hydrolysis of alkaline proteases at an acidic $\mathrm{pH}$, which is also compensated by a long intestine and strong sphincters that allow longer gut residence of the food, in addition to the joint action of digestive hormones such as cholecystokinin that causes peristalsis, increasing surface contact with the enzymatic substrate (Álvarez-González, 2003).

Worth mentioning alkaline proteases may be more stable at different $\mathrm{pH}$ values, because they comprised a greater number of enzymes (trypsin, chymotrypsin, L-aminopeptidase, carboxypeptidase A, elastases, among others), which increases the possibility of hydrolyzing food proteins despite the $\mathrm{pH}$ variation (Alarcón et al., 1998). Instead, acid proteases are often more susceptible to $\mathrm{pH}$ changes, since they only have an enzyme corresponding to pepsin, which when subjected to different $\mathrm{pH}$ values, undergoes changes in its structural configuration or denaturation that leads to partial or total loss of activity (Nalinanon et al., 2010).

Optimum temperature for digestive proteases of $M$. brachyurus has typical values $\left(35^{\circ} \mathrm{C}\right.$ for acidic proteases and $45{ }^{\circ} \mathrm{C}$ for alkaline proteases) that are similar for other fish species. Thus, variations in activity due to temperature depend on the genetic composition and habitat conditions. In this aspect, the optimum temperature of the alkaline proteases is typically $10{ }^{\circ} \mathrm{C}$ higher than the optimum temperature of the acid proteases and also is more thermostable (Álvarez-González, 2003). Usually, the difference between the optimum temperatures of alkaline and acid proteases has been described in carnivorous fish species such as T. thynnus (Essed et al., 2002), B. orbignyanus (García-Carreño et al., 2002) and P. maculatofasciatus (Álvarez-González, 2003). The optimum temperature of acid proteases in M. brachyurus was $35{ }^{\circ} \mathrm{C}$, similar to that described in the hybrid O. niloticus x O. aureus (Jun-sheng et al., 2006), but higher than that found for S. senegalensis (Sáenz de Rodrigáñez et al., 2005), T. orientalis (de la Parra et al., 2007), C. trimaculatum (=Amphilophus trimaculatus) (Toledo-Solís et al., 2015), and A. probatocephalus (Merino-Contreras et al., 2018), with optimum temperature range 35 to $55{ }^{\circ} \mathrm{C}$. The activity of acid proteases is stable up to $45^{\circ} \mathrm{C}$, resulting in values $>100 \%$ for some of the incubation times, but over $60 \%$ of the activity is lost above $55{ }^{\circ} \mathrm{C}$. This could be due to denaturation of pepsin at temperatures over $55{ }^{\circ} \mathrm{C}$, in agreement with results described by Furné et al. (2005). In contrast, alkaline proteases have an optimal temperature of $45{ }^{\circ} \mathrm{C}$, which is less than reported for the Caranx hippos (Linnaeus, 1766), Pseudupeneus maculatus (Bloch, 1793), Sparisoma sp., Hoplias malabaricus (Bloch, 1794) (Alencar et al., 2003), and O. niloticus (Bezerra et al., 2005), species that show an optimum temperature ranging from 50 to $55{ }^{\circ} \mathrm{C}$. The high thermostability of the 
alkaline proteases in M. brachyurus is similar to that reported for A. tropicus (GuerreroZárate et al., 2014), C. trimaculatum (=Amphilophus trimaculatus) (Toledo-Solís et al., 2015), and C. undecimalis (Concha-Frias et al., 2016). It is noteworthy that optimum temperature and thermal stability of the digestive proteases are only operational parameters of enzymes, rather than physiologically relevant results, since activities may vary with enzyme configuration, habitat, environment and genetic aspects of the species (Alarcón et al., 1998; Furné et al., 2005; Tanji et al., 2007). This deficiency in activity is compensated by a longer retention of food in the digestive system to perform the hydrolysis of proteins at lower temperatures than the optimum (Furné et al., 2005; Lazo et al., 2007; Nalinanon et al., 2010; Uscanga et al., 2010).

The seven types of specific inhibitors reduced the activity of alkaline proteases by at least $53 \%$. Of these inhibitors, the group of serine proteases was inhibited by $40 \%$ by Phenyl methyl sulphonyl fluoride (PMSF), and by 35\% and 58\% with ovalbumin and soybean trypsin inhibitor (SBT1), respectively. This pattern in which serine proteases were more markedly affected than the rest of the enzymes was similar to findings in S. aequifasciatus (Chong et al., 2002), T. thynnus (Essed et al., 2002), C. idella (Liu et al., 2008), C. trimaculatum (=Amphilophus trimaculatus) (Toledo-Solís et al., 2015), and C. beani (=Mayaheros beani) (Mártinez-Cárdenas et al., 2017). The other kind of digestive enzyme group subject to high inhibition was the metalloproteases with $55 \%$ inhibition by Phenanthroline and $75 \%$ by ethyl-diamine tetra-acetic acid (EDTA), which are specific inhibitors and inactivators of these enzymes, which are dependent on cofactors such as $\mathrm{Ca}$ and $\mathrm{Mg}$. This indicates that through alkaline digestion, M. brachyurus has the ability to hydrolyze proteins from the carboxyl and amino terminal ends of the peptide chain.

It is important to note that the presence of inhibitors in protein sources should be considered in diet formulation to determine the composition of ingredients that do not contain inhibitors of metalloproteases, aspartic or serine proteases. Our results also showed that TPCK inhibited $80 \%$ of chymotrypsin activity and TLCK inhibited $75 \%$ of trypsin activity. This result was similar to that found in B. orbignyanus (GarcíaCarreño et al., 2002) and S. formosus (Natalia et al., 2004), in which greater inhibition of trypsin than of chymotrypsin by TLCK was documented. Thus, it is confirmed the determination of the types of hydrolases that comprise the digestive proteases of a species using specific inhibitors allows identification of dietary ingredients that may reduce the activity of specific enzymes and thus limit feed digestibility (Essed et al., 2002).

Specific inhibitors of alkaline proteases was performed on SDS-PAGE, six active bands were detected in the control well, differentiating two groups of enzymes: the first group of four active bands with molecular weights between 87.9, 64.8, 59.7 and 52.6 $\mathrm{kDa}$, and the second group of two active bands with molecular weights of 38.1 and 35.2 $\mathrm{kDa}$. The number of active bands found in M. brachyurus was similar to that reported in marine species such as P. maculatofasciatus (Álvarez-González, 2003), and freshwater species such as P. splendida (Uscanga-Martínez et al., 2011), A. tropicus (GuerreroZárate et al., 2014), C. undecimalis (Concha-Frias et al., 2016), and C. beani (=Mayaheros beani) (Mártinez-Cárdenas et al., 2017). In other omnivorous species such as the South American pilchard Sardinops sagax caerulea (=Sardinops sagax (Jenyns, 1842)) (CastilloYáñez et al., 2005) and round sardinella Sardinella aurita Valenciennes, 1847 (Ben Khaled et al., 2011), trypsin showed active bands with different molecular weights ranging 
between 35 and $38.8 \mathrm{kDa}$, while purified chymotrypsin from S. sagax caerulea had a molecular weight of $35.5 \mathrm{kDa}$ (Castillo-Yañez et al., 2009). The inhibitors SBT1 and PMSF, specific for serine protease, presented the highest inhibition as they eliminated three active bands in M. brachyurus, which could be trypsin-like or chymotrypsin-like enzymes (Simpson, 2000; Zhou et al., 2008; Castillo-Yañez et al., 2009; Ben Khaled et al., 2011; Martínez-Cárdenas et al., 2017; Merino-Contreras et al., 2018). On the other hand, the specific inhibitors for metalloproteases PHE and EDTA inhibited two active bands in the first group of enzymes. Therefore, future studies should be conducted with purified enzymes to determine the specific type of enzymes present in M. brachyurus.

In conclusion, juvenile of $M$. brachyurus have a high stability that alkaline digestive proteases that are shown at different $\mathrm{pH}$ and temperature values, so we consider that there are other types of digestive enzymes (trypsin-like, chymotrypsin-like, among others), which may be different to those observed in other species. Likewise, the alkaline proteases of pipefish are more resistant to inhibitors such as SBT1 and PMSF than other fish species, so it is probable that several protein ingredients of different origin can be used for develop a balanced diet, at least in the juvenile period; however, it is necessary to complement this research with in vitro and in vivo studies to develop a basal diet in the culture of M. brachyurus.

\section{ACKNOWLEDGMENTS}

The authors thank the Autonomous University of Nayarit for the donation of specimens, the Universidad Juárez Autónoma de Tabasco for the development of this collaborative research project.

\section{REFERENCES}

- Alarcón FJ, Díaz M, Moyano FJ, Abellan E. Characterization and functional properties of digestive proteases in two sparids; gilthead seabream (Sparus aurata) and common dentex (Dentex dentex). Fish Physiol Biochem. 1998; 19:257-67. https:// doi.org/10.1023/A:1007717708491

- Alencar BR, Biondi MM, Paiva MV, Viera VLA, Carvalho-Junior BL, Bezerra SR. Alkaline proteases from the digestive tract of four tropical fishes. Braz J Food Technol. 2003; 6(2):279-84.

- Álvarez-González CA. Actividad enzimática digestiva y evaluación de dietas para el destete de larvas de la cabrilla arenera Paralabrax maculatofasciatus (Percoidei: serranidae). (PhD Thesis). Centro Interdisciplinario de Ciencias Marinas, La Paz, Baja California Sur, México; 2003. http://repositoriodigital.ipn. $\mathrm{mx} / \mathrm{handle} / 123456789 / 15177$
- Anson ML. The estimation of pepsin, trypsin, papain, and cathepsin with hemoglobin. J Gen Physiol. 1938; 22(1):7989. https://doi.org/10.1085/jgp.22.1.79

\section{- Ben Khaled H, Jellouli K, Souissi} N, Ghorbel S, Barkia A, Nasri M. Purification and characterization of three trypsin isoforms from viscera of sardinelle (Sardinella aurita). Fish Physiol Biochem. 2011; 37:123-33. https://doi.org/10.1007/ s10695-010-9424-5

- Bezerra RS, Lins EJF, Alencar RB, Paiva PMG, Chaves MEC, Coelho LCBB, Carvalho LB. Alkaline proteinase from intestine of Nile tilapia (Oreochromis niloticus). Process Biochem. 2005; 40(5):1829-34. https://doi.org/10.1016/j. procbio.2004.06.066 
- Castillo-Yáñez FJ, Pacheco-Aguilar R, García-Carreño FL, Navarrete-Del Toro MA. Isolation and characterization of trypsin from pyloric caeca of Monterey sardine Sardinops sagax caerulea. Comp Biochem Physiol B Biochem Mol Biol. 2005; 140(1):91-98. https://doi.org/10.1016/j. cbpc.2004.09.031

- Castillo-Yañez FJ, Pacheco-Aguilar R, Lugo-Sanchez ME, Garcia-Sanchez G, Quintero-Reyes IE. Biochemical characterization of an isoform of chymotrypsin from the viscera of Monterey sardine (Sardinops sagax caerulea), and comparison with bovine chymotrypsin. Food Chem. 2009; 112(3):634-39. https://doi.org/10.1016/j. foodchem.2008.06.023

- Chong ASC, Hashim R, Chow-Yang L, Ali AB. Partial characterization and activities of proteases from the digestive tract of discus fish (Symphysodon aequifasciata). Aquaculture. 2002; 203 (3-4):321-33. https://doi.org/10.1016/S00448486(01)00630-5

- Concha-Frias B, Alvarez-González CA, Gaxiola-Cortes MG, Silva-Arancibia AE, Toledo-Agüero PH, Martínez-García R, Camarillo-Coop S, Jimenez-Martinez LD, Arias-Moscoso JL. Partial Characterization of digestive proteases in the common snook Centropomus undecimalis. Int J Biol. 2016; 8(4):1-11. http://dx.doi.org/10.5539/ ijb.v8n4p1

- Cuenca-Soria CA, Álvarez-González CA, Ortiz-Galindo JL, Nolasco-Soria H, TovarRamírez D, Guerrero-Zárate R, Gisbert E. Partial characterisation of digestive proteases of the Mayan cichlid Cichlasoma urophthalmus. Fish Physiol Biochem. 2014; 40:689-99. https://doi.org/10.1007/s10695013-9876-5

- Díaz-López M, Moyano-López FJ, AlarcónLópez FJ, García-Carreño FL, Navarrete del Toro MA. Characterization of fish acid proteases by substrate-gel electrophoresis. Comp Biochem Physiol B Biochem Mol Biol. 1998; 121(4):369-77. https://doi.org/10.1016/ S0305-0491(98)10123-2

- Dunn BM. Determination of protease mechanism. In: Beynon RJ, Bond JS, editors. Proteolytic enzymes: a practical approach. IRL Press Oxford, England, 1989; p.57-81. https://doi.org/10.1016/0307-4412(90)90038-P
- Essed Z, Fernández I, Alarcón FJ, Moyano FJ. Caracterización de la actividad proteasa digestiva de atún rojo Thunnus thynnus (Linnaeus, 1758). Bol Inst Esp Oceanogr. 2002; 18(1-4):99-107.

- Furné M, Hidalgo MC, López A, GarcíaGallego M, Morales AE, Domezain A, Domezainé J, Sanz A. Digestive enzyme activities in Adriatic sturgeon Acipenser naccarii and rainbow trout Oncorhynchus mykiss. A comparative study. Aquaculture. 2005; 250 (1-2):391-98. https://doi. org/10.1016/j.aquaculture.2005.05.017

- García-Carreño FL, Dimes LE, Haard NF. Substrate-gel electrophoresis for composition and molecular weight of proteinases or proteinaceous proteinase inhibitors. Anal Biochem. 1993; 214(1):6569. https://doi.org/10.1006/abio.1993.1457

- García-Carreño LF, AlbuquerqueCavalcanti C, Navarrete del Toro AM, Zaniboni-Filho E. Digestive proteinases of Brycon orbignyanus (Characidae, Teleostei): characteristics and effects of protein quality. Comp Biochem Physiol B Biochem Mol Biol. 2002; 132(2):343-52. https://doi. org/10.1016/s1096-4959(02)00038-6

- Guerrero-Zárate R, Álvarez-González CA, Olvera-Novoa MA, Perales-García N, Frías-Quintana CA, Martínez-García R, Contreras-Sánchez WM. Partial characterization of digestive proteases in tropical gar Atractosteus tropicus juveniles. Fish Physiol Biochem. 2014; 4):1021-29. https://doi.org/10.1007/s10695-013-9902-7

- Jelks HL, Walsh SJ, Burkhead NM, Contreras-Balderas S, Diaz-Pardo E, Hendrickson DA, Lyons J, Mandrak NE, McCormick F, Nelson JS, Platania SP, Porter BA, Renaud CB, Schmitter-Soto JJ, Taylor EB, Warren Jr ML. Conservation status of imperiled North American freshwater and diadromous fishes. Fisheries. 2008; 33(8):372-407. https://doi. org/10.1577/1548-8446-33.8.372

- Kumar S, Garcia-Carreño FL, Chakrabarti R, Toro MA, CórdovaMurueta JH. Digestive proteases of three carps Catla catla, Labeo rohita and Hypophthalmichthys molitrix: Partial characterization and protein hydrolysis efficiency. Aquac Nutr. 2007; 13(5):381-88. https://doi.org/10.1111/j.13652095.2007.00488.x 
- Kunitz M. Crystalline soybean trypsin inhibitor: II. General properties. J Gen Physiol. 1947; 30(4):291-310. https://doi. org/10.1085/jgp.30.4.291

- Laemmli UK. Cleavage of structural proteins during the assembly of the head of bacteriophage T4. Nature. 1970; 227:680-85. https://doi. org/10.1038/227680a0

- Lazo JP, Mendoza R, Holt GJ, Aguilera C, Arnold CR. Characterization of digestive enzymes during larval development of red drum (Sciaenops ocellatus). Aquaculture. 2007; 265(1-4):194-205. https://doi. org/10.1016/j.aquaculture.2007.01.043

- Jun-sheng L, Jian-lin, L, Ting-ting W. Ontogeny of protease, amylase and lipase in the alimentary tract of hybrid juvenile tilapia (Oreochromis niloticus $\mathrm{x}$ Oreochromis aureus). Fish Physiol Biochem. 2006; 32:295-303. https://doi. org/10.1007/s10695-006-9106-5

- Liu ZY, Wang Z, Xu SY, Xu LN. Partial characterization and activity distribution of proteases along the intestine of grass carp, Ctenopharyngodon idella (Val.). Aquac Nutr. 2008; 14(1):31-39. https://doi. org/10.1111/j.1365-2095.2007.00502.x

- Martínez-Cárdenas L, Álvarez-González C, Hernández-Almeida O, FríasQuintana C, Ponce-Palafox J, CastilloVargasmachuca S. Partial characterization of digestive proteases in the green cichlid, Cichlasoma beani. Fishes. 2017; 2(1):4. https://doi.org/10.3390/fishes2010004

- Merino-Contreras ML, Sánchez-Morales F, Jiménez-Badillo ML, Peña-Marín ES, Álvarez-González CA. Partial characterization of digestive proteases in sheepshead, Archosargus probatocephalus (Spariformes: Sparidae). Neotrop Ichthyol. 2018; 16(4):e180020. https://doi. org/10.1590/1982-0224-20180020

- Miller RR, Minckley WL, Norris SM. Freshwater fishes of Mexico. Chicago: University of Chicago Press; 2005.

- Nalinanon S, Benjakul S, Kishimura H. Purification and biochemical properties of pepsins from the stomach of skipjack tuna (Katsuwonus pelamis). Eur Food Res Technol. 2010; 231:259-69. https://doi. org/10.1007/s00217-010-1275-x
- Nalinanon S, Benjakul S, Visessanguan W, Kishimura H. Tuna Pepsin: Characteristics and its use for collagen extraction from the skin of threadfin bream (Nemipterus spp.). J Food Sci. 2008; 73 (5):C413-C419. https://doi. org/10.1111/j.1750-3841.2008.00777.x

- Natalia Y, Hashim R, Ali A, Chong A. Characterization of digestive enzymes in a carnivorous ornamental fish, the Asian bony tongue Scleropages formosus (Osteoglossidae). Aquaculture. 2004; 233(1-4):305-20. https://doi.org/10.1016/j. aquaculture.2003.08.012

- NOAA (National Oceanic and Atmospheric Administration). Endangered and Threatened Species; Establishment of Species of Concern List, Addition of Species to Species of Concern List, Description of Factors for Identifying Species of Concern, and Revision of Candidate Species List Under the Endangered Species Act. National Marine Fisheries Service (NMFS). The Daily Journal of the United States Government. 2004 (Publication date 04/15/2004). Available from https://www. federalregister.gov/d/04-8593

- Nelson JS, Grande TC, Wilson MVH. Fishes of the world, 5th edition. Hoboken, New Jersey: John Wiley \& Sons, Inc; 2016. https://doi.org/10.1002/9781119174844

- de la Parra AM, Rosas A, Lazo JP, Viana MT. Partial characterization of the digestive enzymes of Pacific bluefin tuna Thunnus orientalis under culture conditions. Fish Physiol Biochem. 2007; 33:223-31. https:// doi.org/10.1007/s10695-007-9134-9

- Peña E, Hernández C, Álvarez-González CA, Ibarra-Castro L, Puello-Cruz A, Hardy RW. Comparative characterization of protease activity in cultured spotted rose snapper juveniles (Lutjanus guttatus). Lat Am J Aquat Res. 2015; 43(4):641-50. http:// dx.doi.org/10.3856/vol43-issue4-fulltext-3

- Pujante IM, Díaz-López M, Mancera JM, Moyano FJ. Characterization of digestive enzymes protease and alpha-amylase activities in the thick-lipped grey mullet (Chelon labrosus, Risso 1827). Aquac Res. 2017; 48(2):367-76. https://doi.org/10.1111/are.13038

- Rosa IL, Oliveira TPR, Osorio FM, Morales LE, Castro ALC, Barros GML, Alves RRN. Fisheries and trade of seahorses in Brazil: historical perspective, current trends, and future directions. Biodiv Conserv. 2011; (20):1951-71. https:// doi.org/10.1007/s10531-011-0068-2 
- Sáenz de Rodrigáñez M, Alarcón FJ, Martínez MI, Ruiz F, Díaz M, Moyano FJ. Caracterización de las proteasas digestivas del lenguado senegalés Solea senegalensis Kaup, 1858. Bol Inst Esp Oceanogr. 2005; 21(1-4):95-104.

- Simpson BK. Digestive proteases from marine animals. In: Haard NF, Simpson BK, editors. Seafood enzymes. New York, NY: CRC Press, Taylor \& Francis Group; 2000. p.191-213.

- Stauffer CE. Enzyme assays for food scientists. New York: Van Nostand Reinhold/AVI; 1989.

- Tanji M, Yakabe E, Kageyama T, Shin-ichi Y, Ichinose M, Miki K, Ito

H, Takahashi K. Purification and characterization of pepsinogens from the gastric mucosa of African coelacanth, Latimeria chalumnae, and properties of the major pepsins. Comp Biochem Physiol B Biochem Mol Biol. 2007; 146 (3):412-20. https://doi.org/10.1016/j.cbpb.2006.11.025

- Toledo-Solís FJ, Uscanga-Martínez A, Guerrero-Zárate R, Márquez-Couturier G, Martínez-García R, Camarillo-Coop $\mathrm{S}$, Perales-García N, Rodríguez-Valencia W, Gómez-Gómez M, Álvarez-González CA. Changes on digestive enzymes during initial ontogeny in the three-spot cichlid Cichlasoma trimaculatum. Fish Physiol Biochem. 2015; 41:267-79. https://doi. org/10.1007/s10695-014-0023-8

- Tramati C, Savona B, Mazzola A. A study of the pattern of digestive enzymes in Diplodus puntazzo (Cetti, 1777) (Osteichthyes, Sparidae): Evidence for the definition of nutritional protocols. Aquacult Int. 2005; 13:89-95. https://doi. org/10.1007/s10499-004-9028-0

- Ueberschär B. The use of tryptic enzyme activity measurement as a nutritional condition index: laboratory calibration data and field application. ICES Mar Sci Symp. 1995; 201:119-29.

- Uscanga A, Moyano FJ, Alvarez CA. Assessment of enzymatic efficiency on protein digestion in the tilapia Oreochromis niloticus. Fish Physiol Biochem. 2010; 36:1079-85. https://doi. org/10.1007/s10695-010-9385-8
- Uscanga-Martínez A, Perales-García N, Alvarez-González CA, Moyano FJ, TovarRamírez D, Gisbert GE, Indy JR. Changes in digestive enzyme activity during initial ontogeny of bay snook Petenia splendida. Fish Physiol Biochem. 2011; 37(3):667-80. https://doi.org/10.1007/s10695-011-9467-2

- Walter HE. Proteinases: methods with hemoglobin, casein and azocoll as substrates. In: Bergmeyern HJ, editor. Methods of enzymatic analysis. Weinheim: Verlag Chemie; 1984. p.270-77.

- Wang H, Wang Y, Wang Q, Xue C, Sun M. Purification and characterization of stomach protease from the turbot (Scophthalmus maximus L.). Fish Physiol Biochem. 2006; 32:179-88. https://doi. org/10.1007/s10695-006-0010-9

- Weber K, Osborn M. The reliability of molecular weight determinations by dodecyl sulfate polyacrylamide gel electrophoresis. J Biol Chem. 1969; 244(16):4406-12.

- Wilson AB, Vincent A, Ahnesjö I, Meyer A. Male pregnancy in seahorses and pipefishes (Family Syngnathidae): rapid diversification of paternal brood pouch morphology inferred from a molecular phylogeny. J Hered. 2001; 92(2):159-66. https://doi.org/10.1093/jhered/92.2.159

- Yúfera M, Darías MJ. Changes in the gastrointestinal $\mathrm{pH}$ from larvae to adult in Senegal sole (Solea senegalensis). Aquaculture. 2007; 267(1-4):94-99. https:// doi.org/10.1016/j.aquaculture.2007.02.009

- Zhou Q, Liu G, Huang Y, Weng L, Hara K, Su W, Cao M. Pepsinogens and pepsins from mandarin fish (Siniperca chuatsi). J Agric Food Chem. 2008; 56(13):5401-06. https://doi.org/10.1021/jf800458n 


\section{Neotropical lchthyology}

\section{open access

$$
\text { (c) (1) }
$$

This is an open access article under the terms of the use, distribution and reproduction in why permits provided the original work is properly cited.

Distributed under

Creative Commons CC-BY 4.0

๑ 2020 The Authors.

Diversity and Distributions Published by SBI

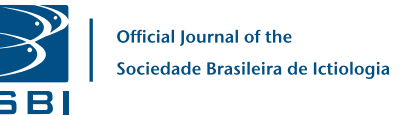

\section{AUTHOR'S CONTRIBUTION @}

Leonardo Martínez-Cárdenas: Conceptualization, Data curation, Investigation, Methodology, Writingoriginal draft, Writing-review \& editing.

Carlos A. Frías-Quintana: Conceptualization, Formal analysis, Investigation, Methodology, Resources, Supervision, Validation, Visualization, Writing-original draft, Writing-review \& editing.

Carlos A. Álvarez-González: Formal analysis, Funding acquisition, Investigation, Methodology, Project administration, Supervision, Writing-original draft, Writing-review \& editing.

Luis D. Jiménez-Martínez: Investigation, Methodology, Supervision, Validation, Visualization, Writingoriginal draft, Writing-review \& editing.

Rafael Martínez-García: Formal analysis, Investigation, Methodology, Supervision, Writing-original draft, Writing-review \& editing.

Oscar U. Hernández-Almeida: Data curation, Formal analysis, Writing-original draft, Writing-review \& editing.

Javier Bello-Pineda: Formal analysis, Investigation, Supervision, Writing-original draft, Writing-review \& editing.

Leonardo U. Arellano-Méndez: Data curation, Formal analysis, Investigation, Writing-original draft, Writing-review \& editing.

Jesús T. Ponce-Palafox: Conceptualization, Formal analysis, Writing-original draft, Writing-review \& editing.

\section{ETHICAL STATEMENT}

Animals were handled in compliance with the Norma Oficial Mexicana NOM-062-ZOO-1999 from Secretaría de Agricultura, Ganadería, Desarrollo Rural, Pesca y Alimentación, the Mexican standards for good welfare practices of laboratory animals.

\section{COMPETING INTERESTS}

The authors declare no competing interests.

\section{HOW TO CITE THIS ARTICLE}

- Martínez-Cárdenas L, Frías-Quintana CA, Álvarez-González CA, Jiménez-Martínez LD, Martínez-García R, Hernández-Almeida OU, Bello-Pineda J, Arellano-Méndez LU, PoncePalafox JT. Partial characterization of digestive proteases in short-tailed pipefish (Microphis brachyurus) juvenile. Neotrop Ichthyol. 2020; 18(2):e190085. https://doi.org/10.1590/19820224-2019-0085 